\title{
The Potential of Nanotechnology in Medically Assisted Reproduction
}

\author{
Mariana H. Remião', Natalia V. Segatto', Adriana Pohlmann², Silvia S. Guterres², \\ Fabiana K. Seixas ${ }^{1}$ and Tiago Collares ${ }^{1 *}$
}

1 Biotechnology Graduate Program, Molecular and Cellular Oncology Research Group, Laboratory of Cancer Biotechnology, Technology Development Center, Federal University of Pelotas, Pelotas, Brazil, ${ }^{2}$ Post-graduation Program in Pharmaceutical Sciences, Federal University of Rio Grande do Sul, Porto Alegre, Brazil

Reproductive medicine is a field of science which searches for new alternatives not only to help couples achieve pregnancy and preserve fertility, but also to diagnose and treat diseases which can impair the normal operation of the reproductive tract. Assisted reproductive technology (ART) is a set of methodologies applied to cases related to infertility. Despite being highly practiced worldwide, ART presents some challenges, which still require special attention. Nanotechnology, as a tool for reproductive medicine, has been considered to help overcome some of those impairments. Over recent years, nanotechnology approaches applied to reproductive medicine have provided strategies to improve diagnosis and increase specificity and sensitivity. For in vitro embryo production, studies in non-human models have been used to deliver molecules to gametes and embryos. The exploration of nanotechnology for ART would bring great advances. In this way, experiments in non-human models to test the development and safety of new protocols using nanomaterials are very important for informing potential future employment in humans. This paper presents recent developments in nanotechnology regarding impairments still faced by ART: ovary stimulation, multiple pregnancy, and genetic disorders. New perspectives for further use of nanotechnology in reproductive medicine studies are also discussed.

\footnotetext{
Keywords: assisted reproductive technologies, nanotechnology, nanobiotechnology, multiple pregnancy, in vitro maturation, gene therapy, embryology
}

\section{REPRODUCTIVE MEDICINE AND NANOTECHNOLOGY}

Infertility and subfertility defined as the difficulty to conceive are conditions affecting people worldwide. The World Health Organization considers infertile couples those who fail to achieve a clinical pregnancy after, at least, 1 year of regular unprotected sexual intercourse (ZegersHochschild et al., 2017). Couples who experience these difficulties can turn to reproductive medicine technologies to help solve the problem. One of the most revolutionary treatments in this area is assisted reproductive technology (ART) comprising of in vitro embryo production (IVEP).

Regarding reproductive medicine, nanotechnology can be very useful in the development of non-invasive detection, diagnosis, and minimally invasive treatment of infertility-related disorders (oncological or non-oncological) (Barkalina et al., 2014a). To improve diagnostics, nanotechnology is applied mainly to the development and improvement of nanobiosensors and imaging techniques. Nanobiosensors are devices capable of identifying antigens, proteins, nucleic acids, and reactive oxygen and nitrogen species with quickness and sensitivity (Shi et al., 2007; Zhu et al., 2015). 
These technologies are underlying the development of interesting 'lab-on-a-chip' tools. Besides advantages of nanotechnology, this tool requires small volumes of analyte and reagents (Craighead, 2006; Hill and Li, 2017). The functionalization of zinc oxide nanoroads - gold nanoparticles (Gasparotto et al., 2017), iron oxide nanoparticles (Pal et al., 2015), and silicacoated gold nanoparticles with cadmium selenide quantum dots (Johari-Ahar et al., 2015) with anti-CA125 antibodies represent successful strategies to develop higher sensitivity tools for ovarian cancer detection. In addition, anti-HE4 antibody attached to silver nanoparticles was also used to develop a fast, specific, and stable ovarian cancer detection system (Yuan et al., 2012).

Biosensors using anti-PSA antibodies to detect PSA antigen represent one of the most used strategies for detection of prostate cancer. Gold nanoparticles functionalized with antiPSA antibodies have been used in a bio-barcode assay showing ultrasensitivity (Thaxton et al., 2009) and in silicon nanowire field-effect transistors providing real-time prostate cancer detection (Presnova et al., 2017). Gold nanoparticles and anti-PSA antibodies supported in graphene oxide (Pal and Khan, 2017) or bound in cuprous oxide@ceric dioxide core-shell nanocomposites (Li et al., 2017) were also used to develop novel, accurate, and sensitive electrochemical immunosensors.

Diagnostic imaging has been improved by metallic and nanostructured particles, as these nanomaterials have great benefits compared to contrast agents. Iron oxide is one of the main contrast agents used for magnetic resonance imaging (MRI), and when nanostructured, it can be functionalized for additional benefits. Iron oxide nanoparticles can be formed in poly(vinyl alcohol), rendering them degradable over time (Bannerman et al., 2017) or, as showed in tumor xenograft animal models, can be associated to diatoms to improve tumor retention when a magnetic field is applied (Todd et al., 2014). In addition, iron oxide nanoparticles can be directed to a tumor site. For example, the functionalization of superparamagnetic iron oxide nanoparticles (SPIONs) with anti-prostate-specific membrane antigen (PSMA) increased the detection limit and the sensitivity of MRI in prostate tumor cell culture (Sillerud, 2016). In addition to iron oxide, other nanomaterials already tested in cell culture and/or animal models can be used as contrast agents to enhance imaging diagnostics, including gold nanoparticles (Indrasekara et al., 2013; Cole et al., 2015), carbon nanotubes (Liu et al., 2007; Vittorio et al., 2011), liposomes (Martina et al., 2005; Mukundan et al., 2006), dendrimers (Miyake et al., 2015), and quantum dots (Guo et al., 2014; Yao et al., 2016).

In the treatment of oncological diseases of the reproductive system, recent drug delivery and cell-target strategies have been developed. For example, one of the main anticancer drugs used, doxorubicin, has been associated to nanoformulations to increase its efficacy. These include mesoporous silica nanoparticles (Guo et al., 2017) and lipid-coated mesoporous iron oxidebased magnetic nanoassemblies (Pradhan et al., 2016) tested in human cell culture and xenograft mouse models, respectively.
PEGylated liposomes have also been tested for cervical and ovarian cancer using human cells (Sriraman et al., 2016). Magnetic nanoparticles (Hua et al., 2017) have been used to treat cervical cancer in human cell cultures and xenograft mice. Other strategies include the delivering of siRNA in cationic dendritic starch (Engelberth et al., 2017), layer-bylayer engineering of upconversion nanoparticles (Lin et al., 2017), and mesoporous silica nanoparticles (Roberts et al., 2017) resulting in improved cell death in human ovarian cancer cells.

For non-oncological diseases of the reproductive system, some alternatives were tested in human cell culture. To treat uterine leiomyoma, strategies included the use of magnetic nanoparticles complexed to adenovirus (Shalaby et al., 2016) and nanoparticles loaded with 2-methoxyestradiol (Ali et al., 2013). In animal models, carbosilane dendrimer (Chonco et al., 2012) and nanoparticles-in-film (Cunha-Reis et al., 2016) were tested for the treatment of HIV infections. Another condition that could impair fertility is endometriosis, and the strategies already generated using nanomaterials are listed in Table 1.

In the field of fertility preservation, nanotechnology was shown to improve the potential of cryopreserved human immature testicular tissue to restore fertility. Dextran-chitosan nanoparticles loaded with vascular endothelial growth factor (VEGF) were tested for tissue engraftment after cryopreservation of the tissue in mice, resulting in higher vascular density and spermatogonia recovery in transplanted tissues (Poels et al., 2016). For female gametes, an interesting strategy for swine oocyte cryopreservation was developed. The addition of low concentrations of hydroxy apatite nanoparticles (less than 0.5\%) in cryoprotectant agents increased the developmental rate of vitrified/devitrified germinal vesicles oocytes (Li et al., 2016). These are a few of the different contributions that nanotechnology has been giving to medically assisted reproduction.

\section{POTENTIAL CONTRIBUTIONS OF NANOTECHNOLOGY TO ASSISTED REPRODUCTIVE TECHNOLOGY}

Although ART is successfully applied as a clinical treatment worldwide, some challenges remain. Because of this, strategies developed in animal models are highly important for identifying new alternatives to overcome these problems. When it comes to ART, embryo development in mammalian models is highly similar to humans (Niemann and Wrenzycki, 2000; Barkalina et al., 2016). Lagomorph, murine, swine, bovine, and non-human primates are the main species used to study IVEP techniques to be applied to humans.

Similarly, the implementation of nanotechnology, which has already been developed for non-human animals, could be applied to assisted reproduction in humans (Langbeen et al., 2015; Barkalina et al., 2016). As mentioned previously, this technology has already been tested and used in sectors adjacent to reproductive medicine. Therefore, the main 
TABLE 1 | Strategies for treating endometriosis using materials in nanoscale.

\begin{tabular}{|c|c|c|c|c|}
\hline Nanomaterial & Strategy & Animal model (cell type) & Main results & Bibliographic reference \\
\hline $\begin{array}{l}\text { Poly(lactic-co-glycolic acid) } \\
\text { (PLGA) nanoparticles }\end{array}$ & $\begin{array}{l}\text { PLGA nanoparticle to carry } \\
\text { an anti-CD4 antibody }\end{array}$ & $\begin{array}{l}\text { Female C57 endometriosis } \\
\text { mouse model }\end{array}$ & $\begin{array}{l}\text { The proposed treatment inhibited } \\
\text { IL-10 and TGF-beta secreted by } \\
\text { CD4+CD25+Treg cells. }\end{array}$ & Liu et al., 2017 \\
\hline $\begin{array}{l}\text { Polyethylenimine-grafted } \\
\text { chitosan oligosaccharide } \\
\text { (CSO-PEI) with hyaluronic } \\
\text { acid (HA) }\end{array}$ & $\begin{array}{l}\text { Gene delivery of aquaporin } \\
2 \text { - small interfering RNA by } \\
\text { polymeric nanoparticles }\end{array}$ & $\begin{array}{l}\text { Ishikawa (IK) cells and female } \\
\text { Sprague-Dawley rats with } \\
\text { induced endometrial lesions }\end{array}$ & $\begin{array}{l}\text { The tested strategy decreased the } \\
\text { endometriotic lesion sizes with } \\
\text { atrophy and degeneration of the } \\
\text { ectopic endometrium. Also, the } \\
\text { epithelial cells of ectopic } \\
\text { endometrium showed a significant } \\
\text { decrease of CD44 expression. }\end{array}$ & Zhao et al., 2016 \\
\hline $\begin{array}{l}\text { Polyvinylpyrrolidone } \\
\text { (PVP K-30) }\end{array}$ & $\begin{array}{l}\text { Nanoencapsulation of } \\
\text { copaiba oil-resin }\end{array}$ & $\begin{array}{l}\text { Primary cell cultures of } \\
\text { endometrial stromal cells } \\
\text { (ESCs) obtained from ectopic } \\
\text { endometrium of patients with } \\
\text { endometriosis (EuESCs), ESCs } \\
\text { obtained from ectopic } \\
\text { endometrium of patients } \\
\text { without endometriosis (CESCs) } \\
\text { and ESCs from endometriotic } \\
\text { lesions (EctESCs) }\end{array}$ & $\begin{array}{l}\text { The proposed method reduced } \\
\text { viability and proliferation of } \\
\text { endometriotic cell cultures upon } \\
\text { COPA nanocomposite treatment. }\end{array}$ & De Almeida Borges et al., 2016 \\
\hline $\begin{array}{l}\text { Poly(lactic-co-glycolic) } \\
\text { (PLGA) nanoparticles }\end{array}$ & $\begin{array}{l}\text { Nanoencapsulation of } \\
\text { epigallocatechin gallate and } \\
\text { doxycycline }\end{array}$ & $\begin{array}{l}\text { Human skin keratinocyte } \\
\text { (HACAT) cell line and Swiss } \\
\text { albino female mice }\end{array}$ & $\begin{array}{l}\text { The proposed treatment } \\
\text { decreased oxidative stress, matrix } \\
\text { metalloproteinase activity, } \\
\text { angiogenesis, endometrial gland } \\
\text { presence and microvessel density, } \\
\text { and improved oocyte quality. }\end{array}$ & Singh et al., 2015 \\
\hline $\begin{array}{l}\text { Unmodified silica } \\
\text { nanoparticles (UMNPs) and } \\
\text { modified by aminopropyl } \\
\text { groups silica nanoparticles } \\
\text { (AMNPs) }\end{array}$ & $\begin{array}{l}\text { Nanoencapsulation of } \\
\text { glucosaminyl muramyl } \\
\text { dipeptide } \\
\text { (N-acetylglucosaminyl-N- } \\
\text { acetylmuramyl-L-alanyl-D- } \\
\text { isoglutamine) } \\
\text { (GMDP) }\end{array}$ & $\begin{array}{l}\text { Peritoneal mononuclear cells } \\
\text { (MNC) derived from peritoneal } \\
\text { fluid of women with } \\
\text { endometriosis }\end{array}$ & $\begin{array}{l}\text { The proposed strategy improved } \\
\text { immunomodulatory effect of } \\
\text { GMDP by the nanoencapsulation } \\
\text { in silica nanoparticles. }\end{array}$ & Antsiferova et al., 2013 \\
\hline $\begin{array}{l}\text { Cerium oxide nanoparticles } \\
\text { (nanoceria) }\end{array}$ & $\begin{array}{l}\text { Mitigation of endometrial } \\
\text { lesions by nanoceria }\end{array}$ & $\begin{array}{l}\text { CD-1 strain Swiss Albino } \\
\text { female mice endometriosis } \\
\text { induced }\end{array}$ & $\begin{array}{l}\text { The nanoceria decreased } \\
\text { oxidative stress, inhibited } \\
\text { angiogenesis, and protected } \\
\text { oocytes from } \\
\text { endometriosis-related adverse } \\
\text { effects. }\end{array}$ & Chaudhury et al., 2013 \\
\hline $\begin{array}{l}\text { Chitosan-derived polymeric } \\
\text { micelles with glycolipid-like } \\
\text { structure }\end{array}$ & $\begin{array}{l}\text { Gene delivery of pigment } \\
\text { epithelium derived factor } \\
\text { gene by micelles }\end{array}$ & $\begin{array}{l}\text { Female Sprague-Dawley rats } \\
\text { with induced endometrial } \\
\text { lesions }\end{array}$ & $\begin{array}{l}\text { The proposed gene therapy } \\
\text { caused a decrease in the sizes of } \\
\text { the endometriotic lesions, an } \\
\text { atrophy and degeneration of } \\
\text { ectopic endometrium, a } \\
\text { significantly decrease in } \\
\text { microvessel density and increased } \\
\text { index of apoptotic in } \\
\text { endometriotic lesions. }\end{array}$ & Zhao et al., 2012 \\
\hline
\end{tabular}

challenges of ART nowadays are how nanotechnology can intervene in order to boost the techniques already used today.

\section{OVARIAN STIMULATION AND IN VITRO MATURATION}

To perform ART procedures, ovarian stimulation is routinelly required in order to obtain a higher number of oocytes and increase the chances of embryo production to enable the selection of the best quality embryos for transfer (Fauser et al., 2005). Despite the increased number of oocytes that can be obtained using this procedure, some impairment has been observed. In addition to the high costs and the modest success rates, there are also potential health risks for the patients such as ovarian hyperstimulation syndrome in case of hyperresponse to ovarian stimulation (Huang et al., 2010).

In vitro maturation (IVM) is one of the most promising strategies for overcoming problems related to ovarian stimulation. Oocyte maturation consists of modification of 
genomic structures, organelle restructurations, and molecular production to allow the gamete to receive spermatozoa for fertilization (Fulka et al., 1998; Mao et al., 2014). Using the IVM technique, immature oocytes are collected from ovaries of non-stimulated patients, followed by selection and exposure to IVM medium consisting of a base medium for cell culture supplemented with hormones, including FSH, LH, and estradiol. However, despite its clinical utility and successfull application in farm animals (Goto et al., 1988; Hwu et al., 1998), IVM of human oocytes remains an experimental approach not widely accepted in fertility clinics worldwide (Chang et al., 2014; Tannus et al., 2017). This is likely due to the lower pregnancy and live birth rates using in vitro compared to in vivo maturated oocytes, likely due to inadequacies of the culture media (Combelles et al., 2002; Ortega-Hrepich et al., 2013).

It is well established that embryo quality is dependent on oocyte quality (Lonergan et al., 2003; Ferris et al., 2016). In addition, correct and complete oocyte maturation is essential to efficient embryo production. Regarding IVM, the process can be disrupted by excess production of ROS, which is one of the major causes of oocyte depletion (Tamura et al., 2008; Karuputhula et al., 2013). For IVM, the addition of antioxidants is helpful, but these molecules may not exert their function with high efficiency due to their instability in in vitro enviroment, making utilization of nanomaterials an interesting strategy for molecule protection (Lucas et al., 2015; Komninou et al., 2016; Remião et al., 2016; Duarah et al., 2017; Manconi et al., 2017). One study from our group has show increased cleavage and blastocyst production rates, decreased ROS levels, and decreased the number of apoptotic cells/blastocyst when bovine oocytes were supplemented with nanoencapsulated melatonin in a IVM medium (Remião et al., 2016).

In another study, tretinoin was nanoencapsulated in lipidcore nanocapsules (LNC) and supplementation with the minor tested concentration $(0.25 \mu \mathrm{M})$ in IVM medium was benneficial for bovine oocytes, resulting in higher cleavage and blastocyst rates, decreased P66Shc protein levels (the $66-\mathrm{kDa}$ isoform of the growth-factor adapter Shc), and decreased ROS production. These benefits were not observed using the same concentration of non-encapsulated tretinoin (Lucas et al., 2015). Therefore, this represents a potential strategy for increasing the effectivness of human IVM and IVEP.

\section{MULTIPLE PREGNANCY}

Multiple pregnancies are a current problem in ART. The incidence of multiple pregnancies is related to pre-term birth, birth of babies with low weight and other complications, and risks to mothers and babies (Fauser et al., 2005; Vulliemoz et al., 2012). The high incidence of multiple pregnancies when using ART is related to the fact that sometimes more than one embryo is transferred into the female reproductive tract (Friedman et al., 2011; Mersereau et al., 2017).
In order to overcome the multiple pregnancy problems in ART, one alternative is the transfer of single embryos performed at a higher frequency (Mancuso et al., 2016). The methodologies assisting this condition are IVM, in vitro blastocyst culture, and embryo cryopreservation, techniques that have been highly studied in small and large animals and have been utilized commercially for many years (Sinclair, 2008).

Preimplantational genetic screening (PGS) and preimplantational genetic diagnosis (PGD) can also be useful to avoid multiple pregnancies, by discarding embryos with genetic disorders. To perform PGS and PGD, embryos are biopsied and evaluated using techniques such as karyotyping, fluorescent in situ hybridization (FISH), quantitative polymerase chain reaction (qPCR), array comparative genomic hybridization (aCGH), and next generation sequencing (NGS) (Chen et al., 2017).

Nanotechnology can help researches improve the application of PGS and PGD. Although highly employed, the current detection methods could be more sensitive and specific, more affordable and accessible to patients, faster, and easier to use to facilitate use in human reproduction clinics. Gold, silver, carbon, and magnetic nanomaterials are the main materials used to develop new methods of genetic diagnostics (Zhu et al., 2015). Nanotechnology combined with colorimetric (Stoeva et al., 2006) and electrochemical (Ozsoz et al., 2003) methods for nucleic acid analysis and detection has brought more sensitivity, lower cost, and increased simplicity and portability to diagnostics. This and other strategies recently developed for DNA analysis can be applied in the future to simplify PGD and PGS diagnostic procedures.

Another strategy for embryo selection is the culture of human embryos until day $5 / 6$, when they reach the blastocyst stage. It has been previously shown that blastocyst transfer (day 5/6) presents better results than cleavage embryos (day 2/3) (Abuzeid et al., 2014; Yin et al., 2017). However, some clinics transfer embryos at the cleavage stage because most embryos fail to reach day $5 / 6$ due to difficulties in mimicking the complexities of the in vivo environment (Alper et al., 2001; Tsirigotis, 1998). In vitro culture and manipulation of gametes and embryos stimulates production of exogenous ROS and leads to oxidative stress, reducing embryo quality (Agarwal et al., 2006; Truong et al., 2016). To overcome the challenge of embryo culture leading up to the blastocyst stage, research groups have looked for alternative approaches to improve in vitro embryo culture, including the addition of antioxidant molecules to the medium.

Studies on IVEP in animal models indicate antioxidant supplementation in medium is beneficial for blastocyst production. Antioxidants presenting beneficial effects in animal model in vitro embryo cultures include L-carnitine (Abdelrazik et al., 2009), hyaluronan (Romek et al., 2017), resveratrol (Salzano et al., 2014), and melatonin (Wang et al., 2013, 2014). However, in the case of bovine IVM, nanotechnology provides interesting alternatives for protecting of these molecules in in vitro environments (Lucas et al., 2015; Komninou et al., 2016; Remião et al., 2016). A recent publication confirmed this approach may represent a relevant alternative: supplementation of IVC medium with melatonin-loaded LNC increased embryo 
quality and blastocyst hatching in a bovine model (Komninou et al., 2016). This strategy is beneficial since the nanocapsules are biodegradable and do not result in toxicity when exposed to bovine oocytes (Lucas et al., 2017) or administered intradermally in rats (Bulcão et al., 2014).

\section{GENETIC DISORDERS}

The development and improvement of genome editing technology in the last few years has introduced gene therapy as a pre-emptive solution for correction of genetic anomalies. Monogenic diseases may be easily corrected using gene therapy, as they are caused by a single defective gene ( $\mathrm{Ma}$ et al., 2017). Some monogenic diseases have already been targeted by gene therapy techniques, including lipoprotein lipase deficiency (Gaudet et al., 2016), hemophilia B (Nathwani et al., 2017), $\beta$-hemoglobinopathies (Negre et al., 2016), WiskottAldrich syndrome (Aiuti et al., 2013; Morris et al., 2017), and inherited retinal degenerations (Gupta and Huckefeldt, 2017), although these diseases have not been treated in embryos.

Two recent reports have already shown the possibility of gene editing human embryos to correct genetic disorders. The studies used the CRISPR-Cas9 method to fix the human $\beta$-globin gene (Liang et al., 2015) and heterozygous MYBPC3 mutation (Ma et al., 2017), mutations responsible for $\beta$-thalassemia and hypertrophic cardiomyopathy, respectively. Although these studies have raised ethical concerns and the technology is still experimental, without proven efficacy and safety, both publications bring an important alternative to reproductive medicine through the treatment of diseases that until now were considered incurable (Ishii, 2017).

Nanotechnology development has resulted in some interesting non-viral strategies for molecule delivery in cells (Barkalina et al., 2015) contributing to the optimization of gene editing. One of them is the study of Sun et al. (2015) that delivered the Cas9 protein and a guide RNA through a DNA nanoclew to human osteosarcoma tumors in mice. Diverse studies have shown efficient gene delivery in mammalian cells via nanomaterials (Guan and Rosenecker, 2017; Riley and Vermerris, 2017). To produce genetically modified embryos, nanomaterials can be used to increase the efficiency of gene transfer via sperm mediated gene transfer. Silica nanoparticles (Barkalina et al., 2014b), magnetic iron nanoparticles (Kim et al., 2010), halloysite clay nanotubes (Campos et al., 2011), and poly(vinyl alcohol)-coated iron oxide nanoparticles (Makhluf et al., 2008) have already shown promise for delivery of nucleic acids and/or proteins to bovine spermatozoa.

Single-cell embryos can also be directly modified using nanomaterials. Das et al. (2016) hypothesized that if singlecell stage zona-free bubaline embryos are transfected with commercial transfecting agents and developed until the blastocyst stage (Selokar et al., 2015), nanomaterials could also be used to introduce genes into embryos at this stage and condition. This could be an alternative to not only viral vectors, but also other expensive methods such as pronuclear microinjection (Das et al., 2016). However, more studies are needed before introducing this technology into practice due to the possible toxic effects.

\section{CHALLENGES FOR THE USE OF NANOTECHNOLOGY IN REPRODUCTIVE SCIENCE}

Nanotechnology has already and can continue to provide advantages for reproductive medicine. Despite the great solutions it can offer, some challenges still faces the use of this technology in medicine. As it is an emerging science, few studies have been performed to validate all the possibilities for treatments or diagnostics. One of the main questions that still need to be addressed regarding the use of nanotechnology is the toxicity it could cause. Despite new diagnostic methodologies being closer to being applied commercially, the ways in which nanomaterials are administered to organisms, embryos, or gametes need to be further studied.

Some nanomaterials are toxic to organism, mainly when exposure occurs during pregnancy and embryo development. For example, when pregnant mice are exposed to titanium dioxide nanomaterials, these materials can cross the placental barrier and cause anatomical defects in the fetuses (Melnik et al., 2013; Naserzadeh et al., 2017). In addition, silver nanoparticles decrease oestrogen plasma levels, increasing the number of resorbed fetuses (Campagnolo et al., 2017) and affecting embryonic growth (Austin et al., 2016). Carbon nanotubes also decrease the number of live fetuses per dam (Fujitani et al., 2015), the number of blood vessels on placenta, and increase the number of abortions (Qi et al., 2014).

Because of this, the utilization of these nanomaterials for reproductive proposes should be done carefully. One alternative is to search for additional nanomaterials that do not present toxicity, with biodegradable structures as the LNC and the dextran/chitosan nanoparticles, representing the most promising nanostructures for use in health applications.

\section{FINAL CONSIDERATIONS}

Despite the recent advances in assisted reproductive technologies, some challenges remain, mainly related to pregnancy rates, multiple births, and genetic disorders. To overcome these problems, new alternatives must be identified. Nanotechnology represents a valuable tool that must be explored further to help researchers identify solutions for reproductive medicine. Nanomaterials can bring specificity, practice, and sensibility to next-generation diagnostic and treatment modalities.

It is expected that, as in other areas of medicine, the employment of nanotechnology could be helpful and beneficial to patients. In addition, researchers must be encouraged to develop more in vitro and in vivo tests using animal models to test safety 
and efficiency of these new methodologies. In addition, human clinical reproductive trials may also help accelerate commercial availability of new alternatives for ART.

\section{AUTHOR CONTRIBUTIONS}

MR, NS, AP, SG, FS, and TC had an equal participation in writing and approving the present manuscript.

\section{REFERENCES}

Abdelrazik, H., Sharma, R., Mahfouz, R., and Agarwal, A. (2009). L-Carnitine decreases DNA damage and improves the in vitro blastocyst development rate in mouse embryos. Fertil. Steril. 91, 589-596. doi: 10.1016/j.fertnstert.2007. 11.067

Abuzeid, M. I., Bolonduro, O., La Chance, J., Abozaid, T., Urich, M., Ullah, K., et al. (2014). Cumulative live birth rate and assisted reproduction: impact of female age and transfer day. Facts Views Vis. Obgyn 6, 145-149.

Agarwal, A., Said, T. M., Bedaiwy, M. A., Banerjee, J., and Alvarez, J. G. (2006). Oxidative stress in an assisted reproductive techniques setting. Fertil. Steril. 86, 503-512. doi: 10.1016/j.fertnstert.2006.02.088

Aiuti, A., Biasco, L., Scaramuzza, S., Ferrua, F., Cicalese, M. P., Baricordi, C., et al. (2013). Lentivirus-based gene therapy of hematopoietic stem cells in Wiskott-Aldrich Syndrome. Science 341:1233151. doi: 10.1126/science.123 3151

Ali, H., Kalashnikova, I., White, M. A., Sherman, M., and Rytting, E. (2013). Preparation, characterization, and transport of dexamethasone-loaded polymeric nanoparticles across a human placental in vitro model. Int. J. Pharm. 454, 149-157. doi: 10.1016/j.ijpharm.2013.07.010

Alper, M. M., Brinsden, P., Fischer, R., and Wikland, M. (2001). To blastocyst or not to blastocyst? That is the question. Hum. Reprod. 16, 617-619. doi: 10.1093/humrep/16.4.617

Antsiferova, Y., Sotnikova, N., and Parfenyuk, E. (2013). Different effects of the immunomodulatory drug GMDP immobilized onto aminopropyl modified and unmodified mesoporous silica nanoparticles upon peritoneal macrophages of women with endometriosis. Biomed Res. Int. 2013:924362. doi: 10.1155/2013/ 924362

Austin, C. A., Hinkley, G. K., Mishra, A. R., Zhang, Q., Umbreit, T. H., Betz, M. W., et al. (2016). Distribution and accumulation of $10 \mathrm{~nm}$ silver nanoparticles in maternal tissues and visceral yolk sac of pregnant mice, and a potential effect on embryo growth. Nanotoxicology 10, 654-661. doi: 10.3109/17435390.2015. 1107143

Bannerman, A. D., Li, X., and Wan, W. (2017). A “degradable” poly(vinyl alcohol) iron oxide nanoparticle hydrogel. Acta Biomater. 58, 376-385. doi: 10.1016/j. actbio.2017.05.018

Barkalina, N., Charalambous, C., Jones, C., and Coward, K. (2014a). Nanotechnology in reproductive medicine: emerging applications of nanomaterials. Nanomedicine 10, 921-938. doi: 10.1016/j.nano.2014.01.001

Barkalina, N., Jones, C., and Coward, K. (2016). Nanomedicine and mammalian sperm: lessons from the porcine model. Theriogenology 85, 74-82. doi: 10.1016/ j.theriogenology.2015.05.025

Barkalina, N., Jones, C., Kashir, J., Coote, S., Huang, X., Morrison, R., et al. (2014b). Effects of mesoporous silica nanoparticles upon the function of mammalian sperm in vitro. Nanomedicine 10, 859-870. doi: 10.1016/j.nano.2013.10.011

Barkalina, N., Jones, C., Wood, M. J. A., and Coward, K. (2015). Extracellular vesicle-mediated delivery of molecular compounds into gametes and embryos: learning from nature. Hum. Reprod. Update 21, 627-639. doi: 10.1093/humupd/ dmv027

Bulcão, R. P., de Freitas, F. A., Dallegrave, E., Venturini, C. G., Baierle, M., Durgante, J., et al. (2014). In vivo toxicological evaluation of polymeric nanocapsules after intradermal administration. Eur. J. Pharm. Biopharm. 86, 167-177. doi: 10.1016/j.ejpb.2013.04.001

Campagnolo, L., Massimiani, M., Vecchione, L., Piccirilli, D., Toschi, N., Magrini, A., et al. (2017). Silver nanoparticles inhaled during pregnancy reach

\section{FUNDING}

This study is part of the National Institute of Science and Technology in Pharmaceutical Nanotechnology: a transdisciplinary approach INCT-NANOFARMA, which is supported by (FAPESP, Brazil) grant no. 2014/50928-2, by (CNPq, Brazil) grant no. 465687/2014-8, CNPq (grant no. 311567/2016-9), and by PRONEX/FAPERGS-CNPq grant no. 165510000467-6.

and affect the placenta and the foetus. Nanotoxicology 11, 687-698. doi: 10.1080/ 17435390.2017.1343875

Campos, V. F., de Leon, P. M. M., Komninou, E. R., Dellagostin, O. A., Deschamps, J. C., Seixas, F. K., et al. (2011). NanoSMGT: transgene transmission into bovine embryos using halloysite clay nanotubes or nanopolymer to improve transfection efficiency. Theriogenology 76, 1552-1560. doi: 10.1016/j. theriogenology.2011.06.027

Chang, E. M., Song, H. S., Lee, D. R., Lee, W. S., and Yoon, T. K. (2014) in vitro maturation of human oocytes: its role in infertility treatment and new possibilities. Clin. Exp. Reprod. Med. 41, 41-46. doi: 10.5653/cerm.2014. 41.2.41

Chaudhury, K., Babu, K. N., Singh, A. K., Das, S., Kumar, A., and Seal, S. (2013). Mitigation of endometriosis using regenerative cerium oxide nanoparticles. Nanomedicine 9, 439-448. doi: 10.1016/j.nano.2012.08.001

Chen, H.-F., Chen, S.-U., Ma, G.-C., Hsieh, S.-T., Tsai, H.-D., Yang, Y.-S., et al. (2017). Preimplantation genetic diagnosis and screening: current status and future challenges. J. Formos. Med. Assoc. doi: 10.1016/j.jfma.2017.08.006 [Epub ahead of print].

Chonco, L., Pion, M., Vacas, E., Rasines, B., Maly, M., Serramía, M. J., et al. (2012). Carbosilane dendrimer nanotechnology outlines of the broad HIV blocker profile. J. Control. Release 161, 949-958. doi: 10.1016/j.jconrel.2012.04.050

Cole, L. E., Ross, R. D., Tilley, J. M., Vargo-Gogola, T., and Roeder, R. K. (2015). Gold nanoparticles as contrast agents in X-ray imaging and computed tomography. Nanomedicine 10, 321-341. doi: 10.2217/nnm.14.171

Combelles, C. M. H., Cekleniak, N. A., Racowsky, C., and Albertini, D. F. (2002). Assessment of nuclear and cytoplasmic maturation in in-vitro matured human oocytes. Hum. Reprod. 17, 1006-1016. doi: 10.1093/humrep/17.4.1006

Craighead, H. (2006). Future lab-on-a-chip technologies for interrogating individual molecules. Nature 442, 387-393. doi: 10.1038/nature05061

Cunha-Reis, C., Machado, A., Barreiros, L., Araújo, F., Nunes, R., Seabra, V., et al. (2016). Nanoparticles-in-film for the combined vaginal delivery of anti-HIV microbicide drugs. J. Control. Release 243, 43-53. doi: 10.1016/j.jconrel.2016. 09.020

Das, J., Choi, Y. J., Song, H., and Ki, J. H. (2016). Potential toxicity of engineered nanoparticles in mammalian germ cells and developing embryos: treatment strategies and anticipated applications of nanoparticles in gene delivery. Hum. Reprod. Update 22, 588-619. doi: 10.1093/humupd/dmw020

De Almeida Borges, V. R., Da Silva, J. H., Barbosa, S. S., Nasciutti, L. E., Cabral, L. M., and De Sousa, V. P. (2016). Development and pharmacological evaluation of in vitro nanocarriers composed of lamellar silicates containing copaiba oil-resin for treatment of endometriosis. Mater. Sci. Eng. C Mater. Biol. Appl. 64, 310-317. doi: 10.1016/j.msec.2016.03.094

Duarah, S., Durai, R. D., and Narayanan, V. B. (2017). Nanoparticle-in-gel system for delivery of vitamin C for topical application. Drug Deliv. Transl. Res. 7, 750-760. doi: 10.1007/s13346-017-0398-Z

Engelberth, S. A., Hempel, N., and Bergkvist, M. (2017). Cationic dendritic starch as a vehicle for photodynamic therapy and siRNA co-delivery. J. Photochem. Photobiol. B Biol. 168, 185-192. doi: 10.1016/j.jphotobiol.2017.02.013

Fauser, B. C. J. M., Devroey, P., and Macklon, N. S. (2005). Multiple birth resulting from ovarian stimulation for subfertility treatment. Lancet 365, 1807-1816. doi: 10.1016/S0140-6736(05)66478-1

Ferris, J., Mahboubi, K., MacLusky, N., King, W. A., and Favetta, L. A. (2016). BPA exposure during in vitro oocyte maturation results in dose-dependent alterations to embryo development rates, apoptosis rate, sex ratio and gene expression. Reprod. Toxicol. 59, 128-138. doi: 10.1016/j.reprotox.2015.12.002 
Friedman, B. E., Davis, L. B., Lathi, R. B., Westphal, L. M., Baker, V. L., and Milki, A. A. (2011). Age-related success with elective single versus double blastocyst transfer. ISRN Obstet. Gynecol. 2011:656204. doi: 10.5402/2011/656204

Fujitani, T., Inomata, A., Ogata, A., Sakamoto, Y., Hirose, A., Nishimura, T., et al. (2015). Comparison of fetal toxicity of various multi-wall carbon nanotubes in mice. Toxicol. Rep. 2, 1404-1408. doi: 10.1016/j.toxrep.2015.07.014

Fulka, J. Jr., First, N. L., and Moor, R. M. (1998). Nuclear and cytoplasmic determinants involved in the regulation of mammalian oocyte maturation. Mol. Hum. Reprod. 4, 41-49. doi: 10.1093/molehr/4.1.41

Gasparotto, G., Costa, J. P. C., Costa, P. I., Zaghete, M. A., and Mazon, T. (2017). Electrochemical immunosensor based on $\mathrm{ZnO}$ nanorods- $\mathrm{Au}$ nanoparticles nanohybrids for ovarian cancer antigen CA-125 detection. Mater. Sci. Eng. C 76, 1240-1247. doi: 10.1016/j.msec.2017.02.031

Gaudet, D., Stroes, E. S., Méthot, J., Brisson, D., Tremblay, K., Sophie, J., et al. (2016). Long-term retrospective analysis of gene therapy with alipogene tiparvovec and its effect on lipoprotein lipase deficiency-induced pancreatitis. Hum. Gene Ther. 27, 916-925. doi: 10.1089/hum.2015.158

Goto, K., Kajihara, Y., Kosaka, S., Koba, M., Nakanishi, Y., and Ogawa, K. (1988). Pregnancies after co-culture of cumulus cells with bovine embryos derived from in-vitro fertilization of in-vitro matured follicular oocytes. Reproduction 83, 753-758. doi: 10.1530/jrf.0.0830753

Guan, S., and Rosenecker, J. (2017). Nanotechnologies in delivery of mRNA therapeutics using nonviral vector-based delivery systems. Gene Ther. 24, 133-143. doi: 10.1038/gt.2017.5

Guo, W., Yang, W., Wang, Y., Sun, X., Liu, Z., Zhang, B., et al. (2014). Color tunable Gd-Zn-Cu-In-S/ZnS quantum dots for dual modality magnetic resonance and fluorescence imaging. Nano Res. 7, 1581-1591. doi: 10.1007/s12274-014-0518-8

Guo, X., Guo, N., Zhao, J., and Cai, Y. (2017). Active targeting co-delivery system based on hollow mesoporous silica nanoparticles for antitumor therapy in ovarian cancer stem-like cells. Oncol. Rep. 38, 1442-1450. doi: 10.3892/or.2017. 5829

Gupta, P. R., and Huckefeldt, R. M. (2017). Gene therapy for inherited retinal degenerations: initial successes and future challenges. J. Neural Eng. 14:51002. doi: 10.1088/1741-2552/aa7a27

Hill, E. K., and Li, J. (2017). Current and future prospects for nanotechnology in animal production. J. Anim. Sci. Biotechnol. 8:26. doi: 10.1186/s40104-0170157-5

Hua, X., Yang, Q., Dong, Z., Zhang, J., Zhang, W., Wang, Q., et al. (2017). Magnetically triggered drug release from nanoparticles and its applications in anti-tumor treatment. Drug Deliv. 24, 511-518. doi: 10.1080/10717544.2016. 1256001

Huang, J. Y. J., Chian, R.-C., and Tan, S. L. (2010). Ovarian hyperstimulation syndrome prevention strategies: in vitro maturation. Semin. Reprod. Med. 28, 519-531. doi: 10.1055/s-0030-1265680

Hwu, Y. M., Lee, R. K., Chen, C. P., Su, J. T., Chen, Y. W., and Lin, S. P. (1998). Development of hatching blastocysts from immature human oocytes following in-vitro maturation and fertilization using a co-culture system. Hum. Reprod. 13, 1916-1921. doi: 10.1093/humrep/13.7.1916

Indrasekara, A. S. D. S., Paladini, B. J., Naczynski, D. J., Starovoytov, V., Moghe, P. V., and Fabris, L. (2013). Dimeric gold nanoparticle assemblies as tags for SERS-based cancer detection. Adv. Healthc. Mater. 2, 1370-1376. doi: 10.1002/ adhm.201200370

Ishii, T. (2017). Reproductive medicine involving genome editing: clinical uncertainties and embryological needs. Reprod. Biomed. Online 34, 27-31. doi: 10.1016/j.rbmo.2016.09.009

Johari-Ahar, M., Rashidi, M. R., Barar, J., Aghaie, M., Mohammadnejad, D., Ramazani, A., et al. (2015). An ultra-sensitive impedimetric immunosensor for detection of the serum oncomarker CA-125 in ovarian cancer patients. Nanoscale 7, 3768-3779. doi: 10.1039/C4NR06687A

Karuputhula, N. B., Chattopadhyay, R., Chakravarty, B., and Chaudhury, K. (2013). Oxidative status in granulosa cells of infertile women undergoing IVF. Syst. Biol. Reprod. Med. 59, 91-98. doi: 10.3109/19396368.2012.743197

Kim, T. S., Lee, S. H., Gang, G. T., Lee, Y. S., Kim, S. U., Koo, D. B., et al. (2010). Exogenous DNA uptake of boar spermatozoa by a magnetic nanoparticle vector system. Reprod. Domest. Anim. 45, e201-e206. doi: 10.1111/j.1439-0531.2009. 01516.x

Komninou, E. R., Remião, M. H., Lucas, C. G., Domingues, W. B., Basso, A. C., Jornada, D. S., et al. (2016). Effects of two types of melatonin-loaded nanocapsules with distinct supramolecular structures: polymeric (NC) and lipid-core nanocapsules (LNC) on bovine embryo culture model. PLOS ONE 11:e0157561. doi: 10.1371/journal.pone.0157561

Langbeen, A., De porte, H. F. M., Bartholomeus, E., Leroy, J. L., and Bols, P. E. J. (2015). Bovine in vitro reproduction models can contribute to the development of (female) fertility preservation strategies. Theriogenology 84, 477-489. doi: 10.1016/j.theriogenology.2015.04.009

Li, F., Li, Y., Feng, J., Dong, Y., Wang, P., Chen, L., et al. (2017). Ultrasensitive amperometric immunosensor for PSA detection based on $\mathrm{Cu} 2 \mathrm{O} @ \mathrm{CeO} 2-\mathrm{Au}$ nanocomposites as integrated triple signal amplification strategy. Biosens. Bioelectron. 87, 630-637. doi: 10.1016/j.bios.2016.09.018

Li, W. J., Zhou, X. L., Liu, B. L., Dai, J. J., Song, P., and Teng, Y. (2016). Effect of nanoparticles on the survival and development of vitrified porcine GV oocytes. Cryo Lett. 37, 401-405.

Liang, P., Xu, Y., Zhang, X., Ding, C., Huang, R., Zhang, Z., et al. (2015). CRISPR/Cas9-mediated gene editing in human tripronuclear zygotes. Protein Cell 6, 363-372. doi: 10.1007/s13238-015-0153-5

Lin, M., Gao, Y., Diefenbach, T. J., Shen, J. K., Hornicek, F. J., Park, Y. I., et al. (2017). Facial layer-by-layer engineering of upconversion nanoparticles for gene delivery: near-infrared-initiated fluorescence resonance energy transfer tracking and overcoming drug resistance in ovarian cancer. ACS Appl. Mater. Interfaces 9, 7941-7949. doi: 10.1021/acsami.6b15321

Liu, Q., Ma, P., Liu, L., Ma, G., Ma, J., Liu, X., et al. (2017). Evaluation of PLGA containing anti-CTLA4 inhibited endometriosis progression by regulating CD4 + CD25 + Treg cells in peritoneal fluid of mouse endometriosis model. Eur. J. Pharm. Sci. 96, 542-550. doi: 10.1016/j.ejps.2016.10.031

Liu, Z., Cai, W., He, L., Nakayama, N., Chen, K., Sun, X., et al. (2007). In vivo biodistribution and highly efficient tumour targeting of carbon nanotubes in mice. Nat. Nanotechnol. 2, 47-52. doi: 10.1038/nnano.2006.170

Lonergan, P., Rizos, D., Gutierrez-Adán, A., Moreira, P. M., Pintado, B., de la Fuente, J., et al. (2003). Temporal divergence in the pattern of messenger RNA expression in bovine embryos cultured from the zygote to blastocyst stage in vitro or in vivo. Biol. Reprod. 69, 1424-1431. doi: 10.1095/biolreprod.103. 018168

Lucas, C. G., Remião, M. H., Bruinsmann, F. A., Lopes, I. A. R., Borges, M. A., Feijó, A. L. S., et al. (2017). High doses of lipid-core nanocapsules do not affect bovine embryonic development in vitro. Toxicol. In Vitro 45(Pt 1), 194-201. doi: 10.1016/j.tiv.2017.09.013

Lucas, C. G., Remião, M. H., Komninou, E. R., Domingues, W. B., Haas, C., Leon, P. M., et al. (2015). Tretinoin-loaded lipid-core nanocapsules decrease reactive oxygen species levels and improve bovine embryonic development during in vitro oocyte maturation. Reprod. Toxicol. 58, 131-139. doi: 10.1016/j. reprotox.2015.10.004

Ma, H., Marti-Gutierrez, N., Park, S.-W., Wu, J., Lee, Y., Suzuki, K., et al. (2017). Correction of a pathogenic gene mutation in human embryos. Nature 548, 413-419. doi: 10.1038/nature23305

Makhluf, S. B.-D., Abu-Mukh, R., Rubinstein, S., Breitbart, H., and Gedanken, A. (2008). Modified PVA-Fe3O4 nanoparticles as protein carriers into sperm cells. Small 4, 1453-1458. doi: 10.1002/smll.200701308

Manconi, M., Marongiu, F., Manca, M. L., Caddeo, C., Sarais, G., Cencetti, C., et al. (2017). Nanoincorporation of bioactive compounds from red grape pomaces: in vitro and ex vivo evaluation of antioxidant activity. Int. J. Pharm. 523, 159-166. doi: 10.1016/j.ijpharm.2017.03.037

Mancuso, A. C., Boulet, S. L., Duran, E., Munch, E., Kissin, D. M., and Van Voorhis, B. J. (2016). Elective single embryo transfer in women less than age 38 years reduces multiple birth rates, but not live birth rates, in United States fertility clinics. Fertil. Steril. 106, 1107-1114. doi: 10.1016/j.fertnstert.2016. 06.017

Mao, L., Lou, H., Lou, Y., Wang, N., and Jin, F. (2014). Behaviour of cytoplasmic organelles and cytoskeleton during oocyte maturation. Reprod. Biomed. Online 28, 284-299. doi: 10.1016/j.rbmo.2013.10.016

Martina, M. S., Fortin, J. P., Ménager, C., Clément, O., Barratt, G., GrabielleMadelmont, C., et al. (2005). Generation of superparamagnetic liposomes revealed as highly efficient MRI contrast agents for in vivo imaging. J. Am. Chem. Soc. 127, 10676-10685. doi: 10.1021/ja0516460

Melnik, E. A., Buzulukov, Y. P., Demin, V. F., Demin, V. A., Gmoshinski, I. V., Tyshko, N. V., et al. (2013). Transfer of silver nanoparticles through the placenta and breast milk during in vivo experiments on rats. Acta Nat. 5, 107-115. 
Mersereau, J., Stanhiser, J., Coddington, C., Jones, T., Luke, B., and Brown, M. B. (2017). Patient and cycle characteristics predicting high pregnancy rates with single-embryo transfer: an analysis of the Society for Assisted Reproductive Technology outcomes between 2004 and 2013. Fertil. Steril. 108, 750-756. doi: 10.1016/j.fertnstert.2017.07.1167

Miyake, Y., Ishikawa, S., Kimura, Y., Son, A., Imai, H., Matsuda, T., et al. (2015). Pharmacokinetics of chiral dendrimer-triamine-coordinated Gd-MRI contrast agents evaluated by in vivo MRI and estimated by in vitro QCM. Sensors 15, 31973-31986. doi: 10.3390/s151229900

Morris, E. C., Fox, T., Chakraverty, R., Tendeiro, R., Snell, K., Rivat, C., et al. (2017). Gene therapy for Wiskott-Aldrich syndrome in a severely affected adult. Blood 130, 1327-1335. doi: 10.1182/blood-2017-04-777136

Mukundan, S., Ghaghada, K. B., Badea, C. T., Kao, C. Y., Hedlund, L. W., Provenzale, J. M., et al. (2006). A liposomal nanoscale contrast agent for preclinical CT in mice. AJR Am. J. Roentgenol. 186, 300-307. doi: 10.2214/AJR. 05.0523

Naserzadeh, P., Ghanbary, F., Ashtari, P., Seydi, E., Ashtari, K., and Akbari, M. (2017). Biocompatibility assessment of titanium dioxide nanoparticles in mice feto- placental unit. J. Biomed. Mater. Res. A 106, 580-589. doi: 10.1002/jbm.a. 36221

Nathwani, A. C., Davidoff, A. M., and Tuddenham, E. G. D. (2017). Advances in gene therapy for Haemophilia. Hum. Gene Ther. 28, 1004-1012. doi: 10.1089/ hum.2017.167

Negre, O., Eggimann, A.-V., Beuzard, Y., Ribeil, J.-A., Bourget, P., Borwornpinyo, S., et al. (2016). Gene therapy of the $\beta$-hemoglobinopathies by lentiviral transfer of the $\beta \mathrm{A}(\mathrm{T} 87 \mathrm{Q})$ - globin gene. Hum. Gene Ther. 27, 148-165. doi: 10.1089/hum.2016.007

Niemann, H., and Wrenzycki, C. (2000). Alterations of expression of developmentally important genes in preimplantation bovine embryos by in vitro culture conditions: implications for subsequent development. Theriogenology 53, 21-34. doi: 10.1016/S0093-691X(99)00237-X

Ortega-Hrepich, C., Stoop, D., Guzmán, L., Van Landuyt, L., Tournaye, H., Smitz, J., et al. (2013). A "freeze-all" embryo strategy after in vitro maturation: a novel approach in women with polycystic ovary syndrome? Fertil. Steril. 100, 1002-1007. doi: 10.1016/j.fertnstert.2013.06.018

Ozsoz, M., Erdem, A., Kerman, K., Ozkan, D., Tugrul, B., Topcuoglu, N., et al. (2003). Electrochemical genosensor based on colloidal gold nanoparticles for the detection of factor $\mathrm{V}$ leiden mutation using disposable pencil graphite electrodes. Anal. Chem. 75, 2181-2187. doi: 10.1021/ac026212r

Pal, M., and Khan, R. (2017). Graphene oxide layer decorated gold nanoparticles based immunosensor for the detection of prostate cancer risk factor. Anal. Biochem. 536, 51-58. doi: 10.1016/j.ab.2017.08.001

Pal, M. K., Rashid, M., and Bisht, M. (2015). Multiplexed magnetic nanoparticleantibody conjugates (MNPs-ABS) based prognostic detection of ovarian cancer biomarkers, CA-125, $\beta-2 \mathrm{M}$ and ApoAl using fluorescence spectroscopy with comparison of surface plasmon resonance (SPR) analysis. Biosens. Bioelectron. 73, 146-152. doi: 10.1016/j.bios.2015.05.051

Poels, J., Abou-Ghannam, G., Decamps, A., Leyman, M., Rieux, A. D., and Wyns, C. (2016). Transplantation of testicular tissue in alginate hydrogel loaded with VEGF nanoparticles improves spermatogonial recovery. J. Control. Release 234, 79-89. doi: 10.1016/j.jconrel.2016.05.037

Pradhan, L., Thakur, B., Srivastava, R., Ray, P., and Bahadur, D. (2016). Assessing therapeutic potential of magnetic mesoporous nanoassemblies for chemo-resistant tumors. Theranostics 6, 1557-1572. doi: 10.7150/thno. 15231

Presnova, G., Presnov, D., Krupenin, V., Grigorenko, V., Trifonov, A., Andreeva, I., et al. (2017). Biosensor based on a silicon nanowire field-effect transistor functionalized by gold nanoparticles for the highly sensitive determination of prostate specific antigen. Biosens. Bioelectron. 88, 283-289. doi: 10.1016/j.bios. 2016.08.054

Qi, W., Bi, J., Zhang, X., Wang, J., Wang, J., Liu, P., et al. (2014). Damaging effects of multi-walled carbon nanotubes on pregnant mice with different pregnancy times. Sci. Rep. 4:4352. doi: 10.1038/srep04352

Remião, M. H., Lucas, C. G., Domingues, W. B., Silveira, T., Barther, N. N., Komninou, E. R., et al. (2016). Melatonin delivery by nanocapsules during in vitro bovine oocyte maturation decreased the reactive oxygen species of oocytes and embryos. Reprod. Toxicol. 63, 70-81. doi: 10.1016/j.reprotox.2016. 05.016
Riley, M., and Vermerris, W. (2017). Recent advances in nanomaterials for gene delivery-a review. Nanomaterials 7:E94. doi: 10.3390/nano705 0094

Roberts, C. M., Shahin, S. A., Wen, W., Finlay, J. B., Dong, J., Wang, R., et al. (2017). Nanoparticle delivery of siRNA against TWIST to reduce drug resistance and tumor growth in ovarian cancer models. Nanomedicine 13, 965-976. doi: 10.1016/j.nano.2016.11.010

Romek, M., Gajda, B., Krzysztofowicz, E., Kucia, M., Uzarowska, A., and Smorag, Z. (2017). Improved quality of porcine embryos cultured with hyaluronan due to the modification of the mitochondrial membrane potential and reactive oxygen species level. Theriogenology 102, 1-9. doi: 10.1016/j.theriogenology.2017. 06.026

Salzano, A., Albero, G., Zullo, G., Neglia, G., Abdel-Wahab, A., Bifulco, G., et al. (2014). Effect of resveratrol supplementation during culture on the quality and cryotolerance of bovine in vitro produced embryos. Anim. Reprod. Sci. 151, 91-96. doi: 10.1016/j.anireprosci.2014.09.018

Selokar, N. L., Saini, M., Agrawal, H., Palta, P., Chauhan, M. S., Manik, R., et al. (2015). Downregulation of DNA methyltransferase 1 in zona-free cloned buffalo (Bubalus bubalis) embryos by small interefering RNA improves in vitro development but does not alter DNA methylation level. Cell. Reprogram. 17, 89-94. doi: 10.1089/cell.2014.0056

Shalaby, S. M., Khater, M. K., Perucho, A. M., Mohamed, S. A., Helwa, I., Laknaur, A., et al. (2016). Magnetic nanoparticles as a new approach to improve the efficacy of gene therapy against differentiated human uterine fibroid cells and tumor-initiating stem cells. Fertil. Steril. 105, 1638-1648. doi: 10.1016/j. fertnstert.2016.03.00

Shi, H., Xia, T., Nel, A. E., and Yeh, J. I. (2007). Part II: coordinated biosensors - development of enhanced nanobiosensors for biological and medical applications. Nanomedicine 2, 599-614. doi: 10.2217/17435889.2. 5.599

Sillerud, L. O. (2016). Quantitative [Fe]MRI of PSMA-targeted SPIONs specifically discriminates among prostate tumor cell types based on their PSMA expression levels. Int. J. Nanomedicine 11, 357-371. doi: 10.2147/IJN.S93409

Sinclair, K. D. (2008). Assisted reproductive technologies and pregnancy outcomes: mechanistic insights from animal studies. Semin. Reprod. Med. 26, 153-161. doi: 10.1055/s-2008-1042954

Singh, A. K., Chakravarty, B., and Chaudhury, K. (2015). Nanoparticle-assisted combinatorial therapy for effective treatment of endometriosis. J. Biomed. Nanotechnol. 11, 789-804. doi: 10.1166/jbn.2015.2020

Sriraman, S. K., Pan, J., Sarisozen, C., Luther, E., and Torchilin, V. (2016). Enhanced cytotoxicity of folic acid-targeted liposomes co-loaded with C6 ceramide and doxorubicin: in vitro evaluation on HeLa, A2780-ADR, and H69-AR Cells. Mol. Pharm. 13, 428-437. doi: 10.1021/acs.molpharmaceut.5b00663

Stoeva, S. I., Lee, J. S., Thaxton, C. S., and Mirkin, C. A. (2006). Multiplexed DNA detection with biobarcoded nanoparticle probes. Angew. Chem. Int. Ed. Engl. 45, 3303-3306. doi: 10.1002/anie.200600124

Sun, W., Ji, W., Hall, J. M., Hu, Q., Wang, C., Beisel, C. L., et al. (2015). Efficient delivery of CRISPR-Cas9 for genome editing via self- assembled DNA nanoclews. Angew. Chem. Int. Ed. Engl. 54, 12029-12033. doi: 10.1002/anie. 201506030

Tamura, H., Takasaki, A., Miwa, I., Taniguchi, K., Maekawa, R., Asada, H., et al. (2008). Oxidative stress impairs oocyte quality and melatonin protects oocytes from free radical damage and improves fertilization rate. J. Pineal Res. 44, 280-287. doi: 10.1111/j.1600-079X.2007.00524.x

Tannus, S., Hatirnaz, S., Tan, J., Ata, B., Tan, S.-L., Hatirnaz, E., et al. (2017). Predictive factors for live birth after in vitro maturation of oocytes in women with polycystic ovary syndrome. Arch. Gynecol. Obstet. doi: 10.1007/s00404017-4561-z [Epub ahead of print].

Thaxton, C. S., Elghanian, R., Thomas, A. D., Stoeva, S. I., Lee, J.-S., Smith, N. D., et al. (2009). Nanoparticle-based bio-barcode assay redefines "undetectable" PSA and biochemical recurrence after radical prostatectomy. Proc. Natl. Acad. Sci. U.S.A. 106, 18437-18442. doi: 10.1073/pnas.0904719106

Todd, T., Zhen, Z., Tang, W., Chen, H., Wang, G., Chuang, Y.-J., et al. (2014). Iron oxide nanoparticle encapsulated diatoms for magnetic delivery of small molecules to tumors. Nanoscale 6, 2073-2076. doi: 10.1039/c3nr05623f

Truong, T. T., Soh, Y. M., and Gardner, D. K. (2016). Antioxidants improve mouse preimplantation embryo development and viability. Hum. Reprod. 31, 1445-1454. doi: 10.1093/humrep/dew098 
Tsirigotis, M. (1998). Blastocyst stage transfer: pitfalls and benefits. Too soon to abandon current practice? Hum. Reprod. 13, 3285-3289. doi: 10.1093/humrep/ 13.12.3285

Vittorio, O., Duce, S. L., Pietrabissa, A., and Cuschieri, A. (2011). Multiwall carbon nanotubes as MRI contrast agents for tracking stem cells. Nanotechnology 22:95706. doi: 10.1088/0957-4484/22/9/095706

Vulliemoz, N. R., McVeigh, E., and Kurinczuk, J. (2012). in vitro fertilisation: perinatal risks and early childhood outcomes. Hum. Fertil. 15, 62-68. doi: 10.3109/14647273.2012.663571

Wang, F., Tian, X., Zhang, L., Tan, D., Reiter, R. J., and Liu, G. (2013). Melatonin promotes the in vitro development of pronuclear embryos and increases the efficiency of blastocyst implantation in murine. J. Pineal Res. 55, 267-274. doi: $10.1111 /$ jpi.12069

Wang, F., Tian, X., Zhou, Y., Tan, D., Zhu, S., Dai, Y., et al. (2014). Melatonin improves the quality of in vitro produced (IVP) bovine embryos: implications for blastocyst development, cryotolerance, and modifications of relevant gene expression. PLOS ONE 9:e93641. doi: 10.1371/journal.pone.009 3641

Yao, H. C., Su, L., Zeng, M., Cao, L., Zhao, W. W., Chen, C. Q., et al. (2016). Construction of magnetic-carbon-quantum-dots-probe-labeled apoferritin nanocages for bioimaging and targeted therapy. Int. J. Nanomedicine 11, 44234438. doi: 10.2147/IJN.S108039

Yin, Y., Chen, G., Li, K., Liao, Q., Zhang, S., Ma, N., et al. (2017). Propensity scorematched study and meta-analysis of cumulative outcomes of day $2 / 3$ versus day 5/6 embryo transfers. Front. Med. 11, 563-569. doi: 10.1007/s11684-0170535-6

Yuan, J., Duan, R., Yang, H., Luo, X., and Xi, M. (2012). Detection of serum human epididymis secretory protein 4 in patients with ovarian cancer using a label-free biosensor based on localized surface plasmon resonance. Int. J. Nanomedicine 7, 2921-2928. doi: 10.2147/IJN.S32641

Zegers-Hochschild, F., Adamson, G. D., Dyer, S., Racowsky, C., de Mouzon, J., Sokol, R., et al. (2017). The international glossary on infertility and fertility care, 2017. Fertil. Steril. 108, 393-406. doi: 10.1016/j.fertnstert.2017.06.005

Zhao, M. D., Cheng, J. L., Yan, J. J., Chen, F. Y., Sheng, J. Z., Sun, D. L., et al. (2016). Hyaluronic acid reagent functional chitosan-PEI conjugate with AQP2siRNA suppressed endometriotic lesion formation. Int. J. Nanomedicine 11, 1323-1336. doi: 10.2147/IJN.S99692

Zhao, M. D., Sun, Y. M., Fu, G. F., Du, Y. Z., Chen, F. Y., Yuan, H., et al. (2012). Gene therapy of endometriosis introduced by polymeric micelles with glycolipid-like structure. Biomaterials 33, 634-643. doi: 10.1016/j.biomaterials. 2011.09.077

Zhu, X., Li, J., He, H., Huang, M., Zhang, X., and Wang, S. (2015). Application of nanomaterials in the bioanalytical detection of disease-related genes. Biosens. Bioelectron. 74, 113-133. doi: 10.1016/j.bios.2015.04.069

Conflict of Interest Statement: The authors declare that the research was conducted in the absence of any commercial or financial relationships that could be construed as a potential conflict of interest.

Copyright (c) 2018 Remião, Segatto, Pohlmann, Guterres, Seixas and Collares. This is an open-access article distributed under the terms of the Creative Commons Attribution License (CC BY). The use, distribution or reproduction in other forums is permitted, provided the original author(s) or licensor are credited and that the original publication in this journal is cited, in accordance with accepted academic practice. No use, distribution or reproduction is permitted which does not comply with these terms. 